\title{
Evaluation of [ ${ }^{131}$ ] ]l- and [177Lu]Lu-DTPA-A11 minibody for radioimmunotherapy in a preclinical model of PSCA-expressing prostate cancer
}

\author{
Wen-Ting K Tsai ${ }^{1,4}$, Kirstin A Zettlitz ${ }^{1,5}$, Magnus Dahlbom², Robert E Reiter ${ }^{3}$, Anna M Wu $\mathbf{u}^{1,5}$ \\ ${ }^{1}$ Crump Institute for Molecular Imaging, Department of Molecular and Medical Pharmacology, \\ David Geffen School of Medicine, UC Los Angeles, CA, USA \\ ${ }^{2}$ Ahmanson Translational Imaging Division, Department of Molecular and Medical Pharmacology, \\ David Geffen School of Medicine, UC Los Angeles, CA, USA \\ ${ }^{3}$ Department of Urology, David Geffen School of Medicine, UC Los Angeles, CA, USA \\ ${ }^{4}$ Current address: Antibody Engineering, Genentech, South San Francisco, CA, USA \\ ${ }^{5}$ Current address: Beckman Research Institute, City of Hope, Duarte, CA
}

\begin{abstract}
Purpose-Radioimmunotherapy uses tumor-specific antibodies to deliver therapeutic radionuclides, but hematological toxicity due to the long serum half-life of intact antibodies remains a challenge. We evaluated a smaller antibody fragment, the minibody, with faster kinetics and a potentially improved therapeutic index.

Procedures-The anti-prostate stem cell antigen (PSCA) minibody (A11 Mb) was radiolabeled with iodine-124 ([ $\left.\left.{ }^{124} \mathrm{I}\right] \mathrm{I}-\mathrm{A} 11 \mathrm{Mb}\right)$ or conjugated with deferoxamine (DFO) and labeled with zirconium-89 ([ $\left.{ }^{89} \mathrm{Zr}\right] \mathrm{Zr}$-DFO-A11 Mb) for surrogate immunoPET to profile pharmacokinetics in a human prostate cancer xenograft model. Subsequently, minibodies labeled with two therapeutic beta-emitters, directly iodinated $\left[{ }^{131} \mathrm{I}\right] \mathrm{I}-\mathrm{A} 11 \mathrm{Mb}$ (non-residualizing) and ${ }^{177} \mathrm{Lu}$ chelated using DTPA ([ $\left.\left.{ }^{177} \mathrm{Lu}\right] \mathrm{Lu}-\mathrm{DTPA}-\mathrm{A} 11 \mathrm{Mb}\right)$ (residualizing), were compared for in vitro antigen-specific cytotoxicity. Full biodistribution studies (in 22Rv1-PSCA tumor bearing and hPSCA knock-in mice) were conducted for dosimetry calculations. Finally, the lead candidate $\left[{ }^{131} \mathrm{I}\right] \mathrm{I}-\mathrm{A} 11 \mathrm{Mb}$ was evaluated in a radioimmunotherapy experiment. Escalating single doses (3.7, 11 or $37 \mathrm{MBq})$ and saline control were administered to 22Rv1-PSCA tumor bearing mice and anti-tumor effects (tumor volume) and toxicity (body weight) were monitored.
\end{abstract}

Corresponding author: Anna M Wu, awu@coh.org, Tel: 1 (626) 218-8051.

Author contributions

WKT, KAZ, MD, RER, AMW designed the research; WKT, KAZ performed the experiments; WKT, KAZ, MD, AMW analyzed the data; WKT, KAZ, AMW wrote the manuscript; WKT, KAZ, MD, RER, AMW read and approved the manuscript.

Conflicts of interest

AM Wu holds ownership interest in and is a consultant/advisory board member for ImaginAb, Inc. The other authors do not have potential conflicts of interest to disclose.

Statement of animal rights

All applicable institutional and/or national guidelines for the care and use of animals were followed. 
Results-Minibodies radiolabeled with therapeutic beta-emitters $\left[{ }^{131} \mathrm{I}\right] \mathrm{I}-\mathrm{A} 11 \mathrm{Mb}$ and $\left[{ }^{177} \mathrm{Lu}\right] \mathrm{Lu}-$ DTPA-A11 Mb exhibited comparable tumor cell growth inhibition in vitro. In vivo surrogate immunoPET imaging using [ ${ }^{89} \mathrm{Zr}$ ]Zr-DFO-A11 Mb showed activity retention in liver and kidney up to $72 \mathrm{~h}$, while $\left[{ }^{124} \mathrm{I}\right] \mathrm{I}-\mathrm{A} 11 \mathrm{Mb}$ cleared from liver, kidney, and blood by $48 \mathrm{~h}$. Based on full biodistribution and dosimetry calculations, administering $37 \mathrm{MBq}\left[{ }^{131} \mathrm{I}\right] \mathrm{I}-\mathrm{A} 11 \mathrm{Mb}$ was predicted to deliver a favorable dose to the tumor ( $35 \mathrm{~Gy}$ ), with a therapeutic index of 22 (tumor:bone marrow). For $\left[{ }^{177} \mathrm{Lu}\right] \mathrm{Lu}-\mathrm{DTPA}-\mathrm{A} 11 \mathrm{Mb}$, the kidneys would be dose-limiting, and the maximum tolerated activity (7.4 MBq) was not predicted to deliver an effective radiation dose to tumor. Radioimmunotherapy with a single dose of $\left[{ }^{131} \mathrm{I}\right] \mathrm{I}-\mathrm{A} 11 \mathrm{Mb}$ showed dose-dependent tumor inhibition with minimal off-target toxicity and improved median survival (19 and $24 \mathrm{~d}, \mathrm{P}<0.001$ ) compared with untreated mice (12 d).

Conclusions-These findings show the potential of the anti-PSCA minibody for targeted radioimmunotherapy with minimal toxicity, and the application of immunoPET and dosimetry for personalized treatment.

\section{Keywords}

Radioimmunotherapy; prostate stem cell antigen; minibody; prostate cancer; immunoPET

\section{Introduction}

While the majority of prostate cancer patients have localized disease at diagnosis, which can be treated with prostatectomy or radiation therapy, 27-53\% will experience biochemical recurrence [1]. Treatment for these patients includes anti-androgens, yet the disease can progress to metastatic castration resistant prostate cancer (mCRPC). Although second generation androgen deprivation therapies such as abiraterone or enzalutamide may extend survival by $1-2$ years, $20-40 \%$ of patients do not respond, and almost all responders develop escape mechanisms and secondary resistance [2]. Therefore, there is a need to explore alternative therapies, such as radioimmunotherapy (RIT). In contrast to external beam radiation therapy, RIT uses the specificity of an antibody to target tumor cells throughout the body and deliver cytotoxic radioactivity that causes DNA damage, reactive oxygen species, and cell death. Although RIT is most widely used to treat lymphoma and leukemia, it has also been explored for treating solid tumors such as prostate cancer [3]. In RIT, the therapeutic index (TI) describes the ratio between a cytotoxic dose to the tumor and the absorbed dose to a radiosensitive tissue (e.g. kidney or bone marrow). The TI is used to determine the therapeutic window, where RIT is effective without unacceptable toxicity, and the corresponding maximum tolerated activity (MTA). Considerations to optimize the TI include the selected antibody (format, affinity, specificity), the targeted antigen (expression in tumor vs normal tissues, fate of the antigen-antibody complex) and the chosen radionuclide (residualizing properties, emitted particulate radiation). Importantly, the potential impact on sensitive tissues such as bone marrow or kidney must be weighed, and indeed can place a limit on radiation dose that can be delivered to tumor.

Antigens selected for preclinical and clinical RIT include prostate specific membrane antigen (PSMA) [4, 5] and human kallikrein-related peptidase 2 [6]. ${ }^{177}$ Lu-labeled PSMAtargeting agents have advanced the furthest in clinical trials, including the small molecules 
$\left[{ }^{177} \mathrm{Lu}\right]$ Lu-PSMA-617 and $\left[{ }^{177} \mathrm{Lu}\right] \mathrm{Lu}-P S M A ~ I \& T ~[7,8]$, as well as ${ }^{177} \mathrm{Lu}-$ labeled J591 intact antibody [4,5]. Alternative targets, such as the prostate stem cell antigen (PSCA), may provide options in case of resistance and allow for combination therapies. PSCA is overexpressed on the cell surface of the majority of primary and metastatic prostate cancers, as well as pancreatic and bladder cancers, and correlates with disease stage [9]. Normal tissue expression of PSCA is restricted to prostate, stomach, and bladder, with little to no expression in radiosensitive tissues (bone marrow, kidney) [9], therefore PSCA is a promising target for antibody-based therapy.

The humanized anti-PSCA full-length antibody $2 \mathrm{~B} 3$ has been previously shown to mediate anti-tumor effects in PSCA-positive xenograft models [10]. While high tumor uptake is desired for therapeutic radionuclide delivery to tumor tissue, the long circulating half-life of intact IgGs is a disadvantage and results in high radiation dose to off-target tissues. For radiometal-conjugated or radioiodinated intact antibodies, exposure of bone marrow to radioactivity from the blood leads to dose-limiting hematologic toxicities [11-13]. Methods to address the toxic side effects of full-length antibody-based radioimmunotherapy include pretargeted RIT $[3,14,15]$. Pretargeting allows an unlabeled antibody to localize to the tumor and clear before the radionuclide is administered and binds to the antibody in vivo, with the overall aim to decrease radiation exposure to healthy tissue and bone marrow. Another promising approach to consider is the use of antibody fragments with a shorter halflife compared to intact antibodies.

Antibody fragments, such as scFv-Fc, [16], small immunoproteins (SIP) [17], diabodies and minibodies $\left(\mathrm{scFv}_{\mathrm{C}} \mathrm{C}_{\mathrm{H}} 3\right)$ [18], feature better tumor penetration and rapid serum clearance due to their lower molecular weight and abrogated FcRn binding. Additionally, engineering can be used to predetermine the route of clearance, which depends on the molecular weight of the fragment. Although antibody fragments have not been greatly explored for RIT, their characteristics could be advantageous to improve patient dosimetry and maximize the TI.

The anti-PSCA A11 minibody (A11 Mb; $80 \mathrm{kDa})$, based on 2B3, has been extensively used in immunoPET studies to detect prostate cancer in a range of preclinical models and showed high tumor-to-background contrast [19-21]. We hypothesize that the A11 Mb radiolabeled with a therapeutic radionuclide will have a suitable TI for RIT of prostate cancer.

The most commonly used radionuclides in RIT are beta-emitters (iodine-131, lutetium-177, yttrium-90), which have a longer range in tissue (tens to hundreds of cells diameters, 0.05$12 \mathrm{~mm}[22,23])$ that can induce damage in cells adjacent to the target site. This "crossfire effect" can be beneficial when targeting larger or heterogenous tumors. Alpha-emitters (e.g. actinium-225) release higher energy but have a shorter range (a few cell diameters, 50-90 $\mu \mathrm{m})$ and are typically more effective for smaller lesions.

The beta-emitting radionuclides iodine-131 and lutetium-177 offer similar half-lives $\left(\mathrm{t}_{1 / 2}=\right.$ $8.0 \mathrm{~d}$ and $6.7 \mathrm{~d}$, respectively) and linear energy transfer (LET) $\left(\mathrm{E}_{\beta(\max )} 606 \mathrm{keV}\right.$ and $2 \mathrm{~mm}$ particle range for iodine-131 and $\mathrm{E}_{\beta(\max )} 497 \mathrm{keV}$ and $1.5 \mathrm{~mm}$ for lutetium-177) but differ with regard to their residualizing properties, which can affect the TI [24]. Non-residualizing radiometabolites, such as iodide/iodotyrosine released from conventionally radioiodinated 
proteins, diffuse out of the cells following internalization and catabolism, and are rapidly excreted. For antigens with slow internalization rates, retention on the cancer cell membrane and low retention in normal tissues results in high tumor to background ratios. In contrast, antibodies chelated and labeled with radiometals such as lutetium-177 are internalized, degraded, and radiolabeled antibody metabolites (such as radiometal-chelator-lysine) are trapped in the lysosomal compartment [25, 26]. Subsequent accumulation of radioactivity in the tumor would be beneficial for RIT; however, the residualizing label will also accumulate in normal organs of clearance (liver and kidney) and potentially cause toxicity.

PSCA has previously been shown to internalize slowly upon antibody binding both in vitro and in vivo [20]; hence we intended to compare dosimetry for $\left[{ }^{131} \mathrm{I}\right] \mathrm{I}-\mathrm{A} 11 \mathrm{Mb}$ and

$\left[{ }^{177} \mathrm{Lu}\right] \mathrm{Lu}-\mathrm{DTPA}-\mathrm{A} 11 \mathrm{Mb}$ to find the preferable beta-emitter for radioimmunotherapy of prostate cancer (Figure 1). We used surrogate $\left[{ }^{124} \mathrm{I}\right] \mathrm{I}-\mathrm{A} 11 \mathrm{Mb}$ and $\left[{ }^{89} \mathrm{Zr}\right] \mathrm{Zr}-\mathrm{DFO}-\mathrm{A} 11 \mathrm{Mb}$ quantitative immunoPET to profile the pharmacokinetics of $\left[{ }^{131} \mathrm{I}\right] \mathrm{I}-\mathrm{A} 11 \mathrm{Mb}$ and $\left[{ }^{177} \mathrm{Lu}\right] \mathrm{Lu}-$ DTPA-A11 Mb, respectively, and inform the biodistribution studies. [ $\left.{ }^{131} \mathrm{I}\right] \mathrm{I}-\mathrm{A} 11 \mathrm{Mb}$ and $\left[{ }^{177} \mathrm{Lu}\right] \mathrm{Lu}-\mathrm{DTPA}-\mathrm{A} 11 \mathrm{Mb}$ ex vivo biodistributions were used to calculate dosimetry and determine the maximum tolerated dose and dose-limiting tissues/organs. The lead candidate, [ $\left.{ }^{131} \mathrm{I}\right] \mathrm{I}-\mathrm{A} 11 \mathrm{Mb}$, was used for RIT in mice bearing PSCA-positive s.c. tumors. Non-tumorbearing human-PSCA knock-in mice were used to assess [ $\left.{ }^{131} \mathrm{I}\right] \mathrm{I}-\mathrm{A} 11 \mathrm{Mb}$ uptake in normal PSCA-expressing tissue.

\section{Methods}

\section{Cell Lines and Tumor Models}

22Rv1 human prostate adenocarcinoma cells were previously transduced to express PSCA (22Rv1-PSCA) [27]. Cells were cultured in RPMI + 10\%FBS. To establish tumors, 22Rv1PSCA cells $\left(0.5-1 \times 10^{6}\right)$ in 1:1 HBSS (Sigma):Matrigel (BD Bioscience) were implanted subcutaneously in the shoulder of 8- to 10-week-old male athymic nude mice (JAX002019, The Jackson Laboratory) [21]. Human PSCA knock-in (hPSCA-KI) C57BL/6J mice (18- to 27-week-old male and female) were bred at UCLA [28]. Protocols for all animal studies were approved by the UCLA Animal Research Committee.

\section{Radiolabeling}

Radiolabeling with iodine-124 and zirconium- 89 was conducted as previously described [20]. A11 Mb was prepared for zirconium- 89 radiolabeling by conjugation with pisothiocyanatobenzyl-deferoxamine (p-SCN-Bn-DFO, B-705, Macrocyclics).

A11 Mb or isotype control (anti-CD20 GA101 cMb [29]) were incubated with 0.2-1.9 MBq/ $\mu \mathrm{g}$ of $\left[{ }^{131} \mathrm{I}\right] \mathrm{Na}$-iodide (3D Imaging LLC) in Pierce Iodination Tubes (Thermo Scientific) (10 min, RT, 0.1 M Tris, pH 8.0).

For lutetium-177 radiolabeling, A11 Mb (50 $\mu \mathrm{L}$ at $4 \mathrm{mg} / \mathrm{ml})$ was incubated with 3-fold molar excess of 2-(p-isothiocyanatophenyl)-cyclohexl-diethylenetriaminepentaacetic acid (p-SCN-Bn-CHX-A"-DTPA, B-355, Macrocyclics) for $1 \mathrm{~h}$ (RT, pH 9). Excess chelator was removed using Micro Bio-Spin ${ }^{\mathrm{TM}}$ Size Exclusion Columns (Bio-Rad). DTPA-conjugated A11 Mb was dialyzed in $0.25 \mathrm{M}$ ammonium acetate $\left(\mathrm{NH}_{4} \mathrm{OAc}\right) \mathrm{pH} 5.5$ and $5 \mathrm{~g} / \mathrm{L}$ Chelex 
100 (Bio-Rad). $\left[{ }^{177} \mathrm{Lu}\right] \mathrm{LuCl}_{3}$ was supplied by the Isotope Program within the Office of Nuclear Physics in the Department of Energy's Office of Science. Lutetium-177 radiolabeling was conducted using standard methods [30]. In short, lutetium-177 was buffered in $250 \mathrm{nM} \mathrm{NH} \mathrm{HAc}_{4} \mathrm{OAc} 5\left(2 \times\right.$ volume of $\left.\left[{ }^{177} \mathrm{Lu}\right] \mathrm{LuCl}_{3}\right)$. DTPA-A11 Mb was incubated with $\left[{ }^{177} \mathrm{Lu}\right] \mathrm{LuCl}_{3}(0.2-1.9 \mathrm{MBq} / \mu \mathrm{g}$ for optimization, $0.4 \mathrm{MBq} / \mu \mathrm{g}$ for biodistributions, $0.2 \mathrm{MBq} / \mu \mathrm{g}$ for cell cytotoxicity) $\left(1 \mathrm{~h}, 37^{\circ} \mathrm{C}\right)$, and the reaction was quenched with $0.25 \mathrm{M} \mathrm{NH}_{4} \mathrm{OAc} /$ acetic acid pH 5.5/50 mM EDTA (10 min).

Radiolabeled proteins were purified using size exclusion columns as described above. Radiolabeling efficiency (LE) and radiochemical purity (RCP) were assessed by Instant Thin Layer Chromatography (ITLC, Biodex Medical System) with the following solvents: $20 \mathrm{mM}$ citrate $\mathrm{pH} 5.0$ ([ $\left.\left.{ }^{89} \mathrm{Zr}\right] \mathrm{Zr}-\mathrm{DFO}-\mathrm{A} 11 \mathrm{Mb}\right), 0.25 \mathrm{M} \mathrm{NH}_{4} \mathrm{OAc} /$ acetic acid $\mathrm{pH}$ 5.5/50 mM EDTA ( $\left.\left[{ }^{177} \mathrm{Lu}\right] \mathrm{Lu}-\mathrm{DTPA}-\mathrm{A} 11 \mathrm{Mb}\right)$, or saline ( $0.9 \%$ sodium chloride) (radioiodinated proteins). The strips were analyzed by gamma counting (Wizard 3" 1480, Perkin-Elmer).

The stability of $\left[{ }^{131} \mathrm{I}\right] \mathrm{I}-\mathrm{A} 11 \mathrm{Mb}$ and $\left[{ }^{177} \mathrm{Lu}\right] \mathrm{Lu}-\mathrm{DTPA}-\mathrm{A} 11 \mathrm{Mb}$ was tested after incubation in mouse serum (Sigma) $\left(37^{\circ} \mathrm{C}\right)$ and assessing the protein-bound activity fraction by ITLC. Immunoreactivity was measured as previously described using 22Rv1-PSCA and 22Rv1 cells [21].

\section{Cell cytotoxicity assay}

22Rv1-PSCA and $22 \mathrm{Rv} 1$ cells $\left(1 \times 10^{4}\right.$ cells/200 $\mu \mathrm{L}$ RPMI) were grown in 96-well plates for 24 h. $\left[{ }^{131} \mathrm{I}\right] \mathrm{I}-\mathrm{A} 11 \mathrm{Mb},\left[{ }^{131} \mathrm{I}\right] \mathrm{I}-$ anti-CD20 cMb, $\left[{ }^{177} \mathrm{Lu}\right] \mathrm{Lu}-\mathrm{DTPA}-\mathrm{A} 11 \mathrm{Mb}$, and A11 Mb were added in triplicate $(0.19 \mathrm{MBq}, 1 \mu \mathrm{g}$ protein) and incubated for 48,72 , or $168 \mathrm{~h}$. Cell viability was assessed using crystal violet. Percent cytotoxicity was calculated by $\left(\mathrm{OD}_{\text {control- }}{ }^{-}\right.$ $\left.\mathrm{OD}_{\text {sample }}\right) / \mathrm{OD}_{\text {control }} \times 100 \%, \mathrm{OD}_{\text {control }}=$ no treatment.

\section{Small animal PET/CT}

Nonspecific iodine uptake in thyroid and stomach was blocked, respectively, with Lugol's iodine and potassium perchlorate (both Sigma-Aldrich) as previously described [31]. Iodine-124- or zirconium-89-labeled A11 Mb (1.5-1.9 MBq, $20 \mu \mathrm{g})$ in $0.1 \mathrm{~mL}$ saline was injected via tail vein into non-tumor-bearing mice (n=3). A 2 h dynamic scan ( 1 frame x 60s interval, $3 \times 180$ s, $4 \times 300$ s, $9 \times 600$ s) was acquired using the G8 microPET scanner (Perkin Elmer), followed by a 1 min microCT scan (CrumpCAT) $(n=1)$. Ten-minute static scans were acquired between 4-72 h. 3D PET reconstruction was based on the Maximum Likelihood Estimation Method (MLEM) algorithm and AMIDE [32] was used for ROI analysis and image display.

\section{Biodistribution}

For ex vivo biodistributions, $\left[{ }^{131} \mathrm{I}\right] \mathrm{I}-\mathrm{A} 11 \mathrm{Mb}$ or $\left[{ }^{177} \mathrm{Lu}\right] \mathrm{Lu}-\mathrm{DTPA}-\mathrm{A} 11 \mathrm{Mb}(0.37-0.67$ $\mathrm{MBq} / 10 \mu \mathrm{g}$ ) were injected via tail vein into tumor-bearing athymic nude mice (22Rv1PSCA, $100-500 \mathrm{~mm}^{3}$ ). [ $\left.{ }^{131} \mathrm{I}\right] \mathrm{I}-\mathrm{A} 11 \mathrm{Mb}$ biodistribution was also performed in normal male and female hPSCA-KI mice. At 8 time points ( $30 \mathrm{~min}-144 \mathrm{~h}, \mathrm{n}=4$ per time point), mice were euthanized, and tissues were collected, weighed, and gamma-counted. The total activity in 
the organ (percentage of injected dose, \%ID) and activity concentration (\%ID per gram of tissue, $\% \mathrm{ID} / \mathrm{g}$ ) were calculated based on a standard of $1 \%$ ID.

\section{Dosimetry}

The non-linear two phase decay equation $\mathrm{y}=\mathrm{m} 1 * \mathrm{e}^{-\mathrm{m} 2 * \mathrm{x}}+\mathrm{m} 3 * \mathrm{e}^{-\mathrm{m} 4 * \mathrm{x}}$ was used to fit the biodistribution data and determine the values for $\mathrm{m} 1=\mathrm{k}_{\text {slow }}, \mathrm{m} 2=\mathrm{tau}_{\text {slow }}, \mathrm{m} 3=\mathrm{k}_{\text {fast }}$, and $\mathrm{m} 4=\mathrm{tau}_{\text {fast }}$, where $\mathrm{x}=$ time, $\mathrm{k}=$ uptake constant, tau=time constant. Calculations were performed using GraphPad Prism (v7.0a). For each organ, the area under the curve (AUC, in units of \%ID*hour) was calculated from the equation AUC $=\mathrm{m} 1 /(\mathrm{m} 2+\lambda)+\mathrm{m} 4 /(\mathrm{m} 3+\lambda)$ using the decay constant $\lambda=\ln (2) / t_{1 / 2}$. The time-integrated activity coefficient (TIAC, $h$ ) was calculated from TIAC $=\mathrm{AUC} / 100 \%$. The TIAC and mouse S-values [33] were used to determine the dose per unit activity $(\mathrm{Gy} / \mathrm{MBq})$ for each organ. The maximum tolerated dose (Gy) for key organs was based on literature [34], with the assumption the values are similar between human and mice. Tumor dose was calculated in OLINDA/EXM v1.1 [35].

\section{Radioimmunotherapy}

Mice bearing 22Rv1-PSCA s.c. tumors were administered 3.7 MBq ( $n=9), 11 \mathrm{MBq}(\mathrm{n}=9)$, or $37 \mathrm{MBq}(\mathrm{n}=9)$ of $\left[{ }^{131} \mathrm{I}\right] \mathrm{I}-\mathrm{A} 11 \mathrm{Mb}(20 \mu \mathrm{g}$ protein dose), or saline $(\mathrm{n}=5)$ when tumors reached $100-200 \mathrm{~mm}^{3}$. Mouse weight and tumor size were recorded every $1-2$ days. Tumors were measured bi-directionally and calculated as (length $\mathrm{x}$ width $\mathrm{x}$ width)/2. Use of objective therapy endpoints was employed to minimize bias in assessing survival: >15-20\% weight loss or tumor size $\geq 1000 \mathrm{~mm}^{3}$.

\section{Tissue Analysis}

Blood samples ( $\mathrm{n}=3$ per group) were collected at therapy endpoint and whole blood count analysis was performed by the UCLA Division of Laboratory Animals Medicine. Acute toxicity to liver (alkaline phosphatase) and kidney (blood urea nitrogen and creatine) was analyzed from serum.

Immunohistochemistry (IHC) was performed by the UCLA Translational Pathology Core Laboratory to stain samples for gamma H2AX (Phospho-Histone H2A.X Rabbit mAb, Cell Signaling Technology) and PSCA (EK5 antibody, UCLA TPCL).

\section{Statistics}

To estimate the interaction between the radionuclide (iodine-131, lutetium-177) and \%ID/ organ by time, repeated measures ANOVA with Geisser-Greenhouse correction (significance threshold=0.05) was performed using Graphpad Prism (v8). To analyze the biodistribution AUC and the cell cytotoxicity assays, multiple Student's t-tests were performed (significance threshold=0.05), and P-values were corrected using the Holm-Šidák method.

Linear mixed model with Type III tests of fixed effects was used to estimate the interaction of tumor growth and administered activity group (IBM SPSS v24, 2016). Median survival was calculated and Kaplan-Meier survival curves were analyzed by log-rank (Mantel-Cox) test. Table values are reported as mean \pm standard deviation. Tumor weight is also reported as mean \pm standard deviation. 


\section{Results \\ $\left[{ }^{131} \mathrm{I}\right] \mathrm{I}-\mathrm{A} 11 \mathrm{Mb}$ and $\left[{ }^{177} \mathrm{Lu}\right]$ Lu-DTPA-A11 Mb radiolabeling with high specific activity}

High specific activities are required to deliver sufficient radioactivity to tumors without the protein dose influencing biodistribution (e.g. by saturating antigen). At the same time, overlabeling can impair antibody binding. To optimize radiolabeling, we compared [ $\left.{ }^{131} \mathrm{I}\right] \mathrm{I}-\mathrm{A} 11$ $\mathrm{Mb}$ with low $(0.15 \mathrm{MBq} / \mu \mathrm{g})$, medium $(0.62 \mathrm{MBq} / \mu \mathrm{g})$ and high $(1.78 \mathrm{MBq} / \mu \mathrm{g})$ specific activity (SA) (Table S1). All three reactions resulted in labeling efficiencies $>90 \%$ and the radiolabel was stable ( $>90 \%$ bound activity at $24 \mathrm{~h}$ ). While low and medium SA [ ${ }^{131}$ I]I-A11 $\mathrm{Mb}$ showed similar cell binding (56-68\% immunoreactivity), the high SA [ $\left.{ }^{131} \mathrm{I}\right] \mathrm{I}-\mathrm{A} 11 \mathrm{Mb}$ showed slightly decreased immunoreactivity at all tested time points (44-61\%). Medium SA was used for biodistributions, and both medium and high SA [ $\left.{ }^{131} \mathrm{I}\right] \mathrm{I}-\mathrm{A} 11 \mathrm{Mb}$ were used in subsequent radioimmunotherapy studies (low and high activity groups, respectively).

Under the conjugation conditions used, low $(0.2 \mathrm{MBq} / \mu \mathrm{g})$ and medium $(0.4 \mathrm{MBq} / \mu \mathrm{g}) \mathrm{SA}$ $\left[{ }^{177} \mathrm{Lu}\right] \mathrm{Lu}-\mathrm{DTPA}-\mathrm{A} 11 \mathrm{Mb}$ reacted with $98 \%$ labeling efficiency (Table S2). Higher activity $(0.7$ and $1.9 \mathrm{MBq} / \mu \mathrm{g})$ in the radiolabeling reaction resulted in lower labeling efficiencies and yielded only slightly higher SA ( 0.44 and $0.48 \mathrm{MBq} / \mu \mathrm{g}$, respectively) indicating saturation of available chelators. Stability (i.e., bound activity at $24 \mathrm{~h}$ ) and immunoreactivity were comparable for all samples (Table S1, S2), and the medium SA $(0.4 \mathrm{MBq} / \mu \mathrm{g})\left[{ }^{177} \mathrm{Lu}\right] \mathrm{Lu}-$ DTPA-A11 was used in subsequent experiments (Table S3).

\section{[ $\left.{ }^{131} \mathrm{I}\right] \mathrm{I}-\mathrm{A} 11 \mathrm{Mb}$ and $\left[{ }^{177} \mathrm{Lu}\right.$ ]Lu-DTPA-A11 Mb induce cytotoxicity in PSCA-positive cells}

A cell cytotoxicity assay was used to determine the ability of radiolabeled A11 Mb to kill tumor cells in an antigen-specific manner (Figure 2). $0.19 \mathrm{MBq}$ of [ $\left.{ }^{131} \mathrm{I}\right] \mathrm{I}-\mathrm{A} 11 \mathrm{Mb}$, $\left[{ }^{177} \mathrm{Lu}\right] \mathrm{Lu}-\mathrm{DTPA}-\mathrm{A} 11 \mathrm{Mb}$, non-specific control [ $\left.{ }^{131} \mathrm{I}\right] \mathrm{I}$-anti-CD20 cMb, or non-radioactive A11 Mb were incubated with 22Rv1-PSCA and 22Rv1 control cells over a time course up to $168 \mathrm{~h}$. Treatment with $\left[{ }^{131} \mathrm{I}\right] \mathrm{I}-\mathrm{A} 11 \mathrm{Mb}$ and $\left[{ }^{177} \mathrm{Lu}\right] \mathrm{Lu}-\mathrm{DTPA}-\mathrm{A} 11 \mathrm{Mb}$ resulted in higher cell death in 22Rv1-PSCA cells compared to PSCA-negative cells and control antibodies at all time points $(\mathrm{P}<0.05)$. At $168 \mathrm{~h},\left[{ }^{131} \mathrm{I}\right] \mathrm{I}-\mathrm{A} 11 \mathrm{Mb}$ and $\left[{ }^{177} \mathrm{Lu}\right] \mathrm{Lu}-\mathrm{DTPA}-\mathrm{A} 11 \mathrm{Mb}$ RIT treatments specifically reduced cell viability to $24 \pm 1 \%$ and $24 \pm 6 \%$, respectively, compared with minimal toxicity of non-targeted [ $\left.{ }^{131} \mathrm{I}\right] \mathrm{I}-$ anti-CD20 cMb,$(81 \pm 2 \%)$ or $\left[{ }^{131} \mathrm{I}\right] \mathrm{I}-$ A11 Mb on PSCA-negative 22Rv1 cells ( $82 \pm 1 \%$ ). Treatment of PSCA-expressing 22Rv1

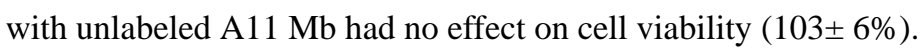

\section{Pharmacokinetics of [ ${ }^{124}$ I]l-A11 $\mathrm{Mb}$ and [ ${ }^{89} \mathrm{Zr}$ ]Zr-DFO-A11 Mb in non-tumor-bearing mice}

Serial immunoPET imaging and ROI quantification using the positron-emitter surrogates $\left[{ }^{124} \mathrm{I}\right] \mathrm{I}-\mathrm{A} 11 \mathrm{Mb}$ and $\left[{ }^{89} \mathrm{Zr}\right] \mathrm{Zr}-\mathrm{DFO}-\mathrm{A} 11 \mathrm{Mb}$ guided subsequent studies evaluating therapeutic [ $\left.{ }^{131} \mathrm{I}\right] \mathrm{I}-\mathrm{A} 11 \mathrm{Mb}$ and $\left[{ }^{177} \mathrm{Lu}\right] \mathrm{Lu}-\mathrm{DTPA}-\mathrm{A} 11 \mathrm{Mb}$. As expected, $\left[{ }^{124} \mathrm{I}\right] \mathrm{I}-\mathrm{A} 11 \mathrm{Mb}$ (non-residualizing radioiodine) cleared from blood, liver, and kidneys by $24-48 \mathrm{~h}$ p.i. (Figure 3A), as confirmed by ROI quantification of the heart (representative of blood), liver, and kidney (Figure 3B). In contrast, [ $\left.{ }^{89} \mathrm{Zr}\right] \mathrm{Zr}$-DFO-A11 Mb (residualizing radiometal) resulted in retention of activity in the liver and kidneys at $72 \mathrm{~h}$ (Figure 3C, 3D), and therefore the $144 \mathrm{~h}$ time point was added for the subsequent biodistribution study. 


\section{Comparison of $\left[{ }^{131} \mathrm{I}\right] \mathrm{I}-\mathrm{A} 11 \mathrm{Mb}$ and $\left[{ }^{177} \mathrm{Lu}\right]$ Lu-DTPA-A11 Mb dosimetry predicts a higher therapeutic index $(\mathrm{TI})$ for $\left[{ }^{131} \mathrm{I}\right] \mathrm{I}-\mathrm{A} 11 \mathrm{Mb}$}

Radiation doses for mouse organs were calculated for iodine-131 and lutetium-177 The ex vivo biodistribution data (22Rv1-PSCA s.c. tumor-bearing nude mice) were used to plot decay-corrected \%ID time activity curves (Figure 4A, 4B) and to calculate the corresponding area under the curves, which represent total activity in the organ and were used to estimate dose to organ per activity administered (Table 1). Similar to the $\left[{ }^{124} \mathrm{I}\right] \mathrm{I}-\mathrm{A} 11$ $\mathrm{Mb}$ images and ROI analysis, $\left[{ }^{131} \mathrm{I}\right] \mathrm{I}-\mathrm{A} 11 \mathrm{Mb}$ total activity was low in the kidneys $(17 \% \mathrm{ID} * \mathrm{~h})$ and liver $(31 \% \mathrm{ID} * \mathrm{~h})$, corresponding to a $90 \mathrm{mGy} / \mathrm{MBq}$ dose per activity for kidneys and $16 \mathrm{mGy} / \mathrm{MBq}$ for liver. The maximum tolerated activity (MTA) for [ $\left.{ }^{131} \mathrm{I}\right] \mathrm{I}-\mathrm{A} 11$ $\mathrm{Mb}$ was $37 \mathrm{MBq}$ (tumor:bone marrow dose $=22$ ) (Table 1), and the bone marrow was the dose-limiting tissue (based on previously published dose estimates) [34]. In comparison, $\left[{ }^{177} \mathrm{Lu}\right] \mathrm{Lu}-\mathrm{DTPA}-\mathrm{A} 11 \mathrm{Mb}$ total activity was high in kidneys $(750 \% \mathrm{ID} * \mathrm{~h})$ and liver $(850 \% \mathrm{ID} * \mathrm{~h})$, and the kidneys were estimated to receive a high dose per activity administered (3020 mGy/MBq) and were the dose-limiting tissue. This translated to a lower MTA for $\left[{ }^{177} \mathrm{Lu}\right]$ Lu-DTPA-A11 Mb (7.4 MBq, tumor:kidney dose $\left.=0.5\right)$ (Table 1). The dose delivered to $0.1 \mathrm{~g}$ tumor from administering the MTA of $\left[{ }^{131} \mathrm{I}\right] \mathrm{I}-\mathrm{A} 11 \mathrm{Mb}(37 \mathrm{MBq})$ or $\left[{ }^{177} \mathrm{Lu}\right] \mathrm{Lu}-\mathrm{DTPA}-\mathrm{A} 11 \mathrm{Mb}(7.4 \mathrm{MBq})$ was estimated to be $35 \mathrm{~Gy}$ and $11 \mathrm{~Gy}$, respectively. In summary, $\left[{ }^{131} \mathrm{I}\right] \mathrm{I}-\mathrm{A} 11 \mathrm{Mb}$ offered a higher MTA and TI and was chosen for the subsequent in vivo RIT studies.

\section{[ $\left.{ }^{131} \mathrm{I}\right] \mathrm{l}-\mathrm{A} 11 \mathrm{Mb}$ radioimmunotherapy inhibited tumor growth and improved survival}

[ $\left.{ }^{131} \mathrm{I}\right] \mathrm{I}-\mathrm{A} 11 \mathrm{Mb}$ RIT was evaluated in a dose escalation study (single injection of $0,3.7,11$ or $37 \mathrm{MBq}$ ) in 22Rv1-PSCA s.c. tumor-bearing mice. Tumor growth was monitored closely, and mice were terminated when tumors reached $\sim 1 \mathrm{~g}$. Treatment with $\left[{ }^{131} \mathrm{I}\right] \mathrm{I}-\mathrm{A} 11 \mathrm{Mb}$ inhibited tumor growth in a dose-dependent manner, with significant effects $(\mathrm{P}<0.001)$ in the groups receiving the highest doses (37 and $11 \mathrm{MBq}$ ) (Figure 5A). Tumor growth inhibition resulted in significantly extended median survival in the $11 \mathrm{MBq}(18 \mathrm{~d})$ and $37 \mathrm{MBq}(24 \mathrm{~d})$ groups compared to control mice receiving saline (12 d) ( $\mathrm{P}<0.001)$ (Figure 5B). The average tumor weight at time of sacrifice was similar for $3.7 \mathrm{MBq}(1060 \pm 264 \mathrm{mg}), 11 \mathrm{MBq}(1050$ $\pm 224 \mathrm{mg}$ ), and control groups ( $989 \pm 308 \mathrm{mg}$ ), and was slightly lower for the $37 \mathrm{MBq}$ group ( $831 \pm 165 \mathrm{mg}$ ), confirming minimal bias in assessing survival (Figure 5C). The tumor from a mouse treated with $37 \mathrm{MBq}\left[{ }^{131} \mathrm{I}\right] \mathrm{I}-\mathrm{A} 11 \mathrm{Mb}$ for $48 \mathrm{~h}$ was stained positively by IHC for $\gamma \mathrm{H} 2 \mathrm{AX}$, a marker for DNA double-stranded breaks, demonstrating RIT-induced DNA damage at early time points (Figure 5D).

\section{[ $\left.{ }^{131} \mathrm{I}\right] \mathrm{I}-\mathrm{A} 11 \mathrm{Mb}$ radioimmunotherapy did not lead to acute off-target toxicity}

All mice recovered from an initial drop in body weight observed among all therapy and control groups, with the exception of one mouse in the $37 \mathrm{MBq}$ group (Figure S1). Complete blood counts at the end of the study were not significantly different between control and therapy groups ( $\mathrm{P}>0.05)$ (Figure S2A). Biochemicals representative of liver damage (alkaline phosphatase, alanine aminotransferase) and kidney damage (blood urea nitrogen, creatine) were not higher in mice receiving $37 \mathrm{MBq}\left[{ }^{131} \mathrm{I}\right] \mathrm{I}-\mathrm{A} 11 \mathrm{Mb}(\mathrm{n}=3)$ compared to mice 
that did not receive treatment (Figure S2B). In summary, we did not observe any off-target toxicity or side effects throughout the duration of treatment.

\section{Normal tissue expression of PSCA did not affect dosimetry estimations}

$\left[{ }^{131} \mathrm{I}\right] \mathrm{I}-\mathrm{A} 11 \mathrm{Mb}$ biodistributions were completed in hPSCA KI mice in order to evaluate whether normal expression of hPSCA in stomach, prostate, kidney, and bladder would alter the dosimetry calculations or lead to toxicity. Comparison of biodistributions of male hPSCA mice at $2 \mathrm{~h}, 4 \mathrm{~h}, 8 \mathrm{~h}, 24 \mathrm{~h}$, and $48 \mathrm{~h}$ and of female hPSCA mice at $8 \mathrm{~h}$ (Table S4) with the time activity curves from nude mice (Figure S3) suggests normal PSCA expression would not alter the dosimetry estimation of $\left[{ }^{131} \mathrm{I}\right] \mathrm{I}-\mathrm{A} 11 \mathrm{Mb}$ RIT or lead to increased dose to stomach, kidney, or bladder.

Female mice were included in this study because they typically have smaller organs, and toxicity to the ovaries is a potential concern [36] for radioimmunotherapy in other PSCA cancer models (pancreatic, bladder). No significant difference was observed between the biodistributions of male and female hPSCA mice and RIT will likely not result in increased toxicity in female mice.

\section{Discussion}

With no available treatment options for advanced metastatic prostate cancer, there is a need for the development of efficacious new therapies. Radioimmunotherapy is a promising targeted approach, with prostate cancer-specific antibodies directing therapeutic radionuclides to both primary tumor and metastatic lesions, which are commonly found in the bone and lymph nodes. RIT has been successfully used to treat hematological cancers, which are inherently radiosensitive and accessible for antibody targeting, but has not progressed as treatment for solid tumors. Compared to leukemias and lymphomas, treating solid tumors requires the delivery of a higher radiation dose (35-100 Gy) [34], which is typically limited by hematological toxicity due to the long circulation time of full-length antibodies.

In this study, we used an engineered antibody fragment (minibody, $80 \mathrm{kDa}$ ), to circumvent some of the limitations of using intact antibodies for targeted radionuclide therapy. Prolonged blood retention of whole antibodies exposes the bone marrow to elevated radiation for days, resulting in dose-limiting toxicity. In contrast, using a radiolabeled minibody, deletion of the $\mathrm{C}_{\mathrm{H}} 2$ domain removes $\mathrm{FcRn}$ interaction, resulting in rapid clearance and reduced radiation exposure of the bone marrow. Furthermore, the molecular weight of the minibody (above the threshold for renal clearance) should direct clearance to the liver and spare the more radiosensitive kidneys.

Previously, the anti-PSCA minibody (A11 Mb) was successfully used as an immunoPET tracer showing specific cancer targeting and favorable pharmacokinetics in a variety of prostate tumor models (moderate to high PSCA-expressing s.c., orthotopic, and intratibial tumors [19-21]). To develop A11 Mb-based RIT for prostate cancer, the corresponding PET agents labeled with iodine-124 or zirconium- 89 were employed to assess overall pharmacokinetics and select time points for the ex vivo biodistribution and dosimetry 
studies. For therapy, the A11 Mb was successfully radiolabeled with beta emitters iodine-131 and lutetium-177, and both demonstrated antigen-specific cytotoxicity in vitro. Dosimetry comparing radioiodinated and radiometal-labeled A11 Mb identified [ $\left.{ }^{131} \mathrm{I}\right] \mathrm{I}-\mathrm{A} 11$ $\mathrm{Mb}$ as the RIT with the higher TI; and the estimated maximum tolerated administered activity of $37 \mathrm{MBq}$, it was projected to deliver $35 \mathrm{~Gy}$ to the tumor. In contrast, $\left[{ }^{177} \mathrm{Lu}\right] \mathrm{Lu}-$ DTPA-A11 Mb was projected to delivery only $11 \mathrm{~Gy}$ to tumor when administered at 7.4 $\mathrm{MBq}$, an activity level limited by the expected high kidney dose. In vivo therapy studies confirmed that $\left[{ }^{131} \mathrm{I}\right] \mathrm{I}-\mathrm{A} 11 \mathrm{Mb}$ RIT inhibits the growth of subcutaneous PSCA-expressing $22 \mathrm{Rv} 1$ tumors in a dose-dependent manner. Furthermore, as expected, $\left[{ }^{131} \mathrm{I}\right] \mathrm{I}-\mathrm{A} 11 \mathrm{Mb}$ with a short serum half-life $(\sim \mathrm{h})$ caused minimal off-target toxicity.

The concept of using smaller antibody fragments with optimized pharmacokinetics for RIT has been successfully employed by other groups. For example, Tijink et al used a similar sized antibody fragment (small immunoprotein, [ $\left.{ }^{131} \mathrm{I}\right] \mathrm{I}-\mathrm{L} 19-\mathrm{SIP}, \sim 80 \mathrm{kDa}$ ) against fibronectin for RIT in preclinical models of both head and neck and colorectal cancer [17, 37]. Similar to our studies, $\left[{ }^{131} \mathrm{I}\right] \mathrm{I}-\mathrm{L} 19-\mathrm{SIP}$ had a more favorable TI compared to $\left[{ }^{177} \mathrm{Lu}\right] \mathrm{Lu}-$ DOTA-L19-SIP [37]. However, the molecular size of the antibody fragment is only one aspect in the efficacy of any given RIT and other aspects (vasculature and permeability, interstitial pressure, heterogenous antigen expression or downregulation) might affect treatment success. Another important consideration is the metabolism of the antibodyantigen complex and subsequent trapping or release of radionuclides. We have previously shown that PSCA exhibits a slow internalization rate [20] and therefore decided to compare a non-residualizing and a residualizing radionuclide with similar physical half-lives and beta-ranges [24]. Both [ $\left.{ }^{131} \mathrm{I}\right] \mathrm{I}-\mathrm{A} 11 \mathrm{Mb}$ and $\left[{ }^{177} \mathrm{Lu}\right] \mathrm{Lu}-\mathrm{DTPA}-\mathrm{A} 11 \mathrm{Mb}$ demonstrated similar antigen-specific cytotoxicity in vitro within $24 \mathrm{~h}$, confirming that internalization of antibody-antigen complexes and possible accumulation of radioactivity does not affect cytotoxicity within this timeframe.

The impact of internalization became more obvious in the in vivo biodistribution and dosimetry studies. There was a significant interaction between radionuclide and time on the total organ activity $(\mathrm{P}<0.0001)$. Due to the metabolism and clearance of $\left[{ }^{131} \mathrm{I}\right] \mathrm{I}-\mathrm{A} 11 \mathrm{Mb}$, the total dose for each organ was below the tumor dose calculated for a $0.1 \mathrm{~g}$ tumor $(940 \mathrm{mGy} /$ $\mathrm{MBq}$ ), and the dose-limiting organ was the bone marrow. For [ $\left.{ }^{177} \mathrm{Lu}\right] \mathrm{Lu}-\mathrm{DTPA}-\mathrm{A} 11 \mathrm{Mb}$, the kidney dose (3020 mGy/MBq) and liver dose (280 mGy/MBq) were high due to residualization of the radiometabolites in these clearance organs, and the kidneys were predicted to be dose-limiting. In summary, $\left[{ }^{131} \mathrm{I}\right] \mathrm{I}-\mathrm{A} 11 \mathrm{Mb}$ allowed for a 5-fold higher administered activity $(37 \mathrm{MBq})$ compared with [ $\left.{ }^{177} \mathrm{Lu}\right] \mathrm{Lu}-\mathrm{DTPA}-\mathrm{A} 11(7.4 \mathrm{MBq})$, potentially delivering a 3 -fold higher dose to a $0.1 \mathrm{~g}$ tumor $\left(35 \mathrm{~Gy}\right.$ for $\left[{ }^{131} \mathrm{I}\right] \mathrm{I}-\mathrm{A} 11 \mathrm{Mb}$ and $11 \mathrm{~Gy}$ for $\left.\left[{ }^{177} \mathrm{Lu}\right] \mathrm{Lu}-\mathrm{DTPA}-\mathrm{A} 11\right)$. The renal clearance of the minibody was not expected, as other minibodies clear primarily to the liver [29,38]. Biophysical characterization of the A11 Mb indicates that the $\mathrm{scFv}-\mathrm{C}_{\mathrm{H}} 3$ homodimer is intact and functional [19], but may have a more compact hydrodynamic diameter allowing renal filtration.

Quantitative imaging is crucial for patient-specific dosimetry and treatment planning. Many clinical theranostic agents have been useful to guide patient treatments, including $\left[{ }^{68} \mathrm{Ga}\right]$ PSMA-11/[ $\left.{ }^{177} \mathrm{Lu}\right]$ PSMA-617 [39] and $\left[{ }^{111} \mathrm{In}\right] /\left[{ }^{90} \mathrm{Y}\right]$-labeled ibritumomab tiuxetan 
[40]. In our study, [ $\left.{ }^{124} \mathrm{I}\right] \mathrm{I}-\mathrm{A} 11 \mathrm{Mb}$ and $\left[{ }^{89} \mathrm{Zr}\right] \mathrm{Zr}-\mathrm{DFO}-\mathrm{A} 11 \mathrm{Mb}$ were useful surrogates to profile the pharmacokinetics of radiolabeled A11 Mb. For example, $\left[{ }^{89} \mathrm{Zr}\right] \mathrm{Zr}$-DFO-A11 Mb immunoPET showed kidney activity at the late time point $(72 \mathrm{~h})$, suggesting RIT using a radiometal-A11 $\mathrm{Mb}$ conjugate could be limited by renal toxicity. These observations were confirmed by biodistribution studies obtained from mice injected with [ $\left.{ }^{131} \mathrm{I}\right] \mathrm{I}-\mathrm{A} 11 \mathrm{Mb}$ or $\left[{ }^{177} \mathrm{Lu}\right] \mathrm{Lu}-\mathrm{DTPA}-\mathrm{A} 11 \mathrm{Mb}$. Deriving estimated effective doses from small animal PET is complicated by small mouse organs, separating them from adjacent tissues, partial volume effects, and blood circulation times [20]. However, whole-body imaging plays an important role in initial clinical evaluation and radiation dosimetry of new tracers in patients [41]. Radiolabeled A11 Mb as a theranostic, could be used for PET imaging to confirm PSCAexpression, radiation dosimetry and personalize dosing, prior to subsequent RIT and furthermore, monitor response to therapy.

Limitations of the study include the unexpected renal clearance of A11 Mb, which prevented pursuing lutetium-177 and potentially achieving a higher therapeutic index. The A11 Mb could be re-engineered to a larger fragment, such as scFv-Fc [16], to further shift clearance to the liver and allow for a higher activity of lutetium-177 to be administered with subsequently higher tumor uptake. Another limitation is the use of an s.c. mouse model without an intact immune system. PSCA-targeted RIT should be evaluated further in the hPSCA knock-in (KI) mouse model, which was previously used for imaging of PSCApositive tumors and metastases $[42,43]$. The biodistributions completed in hPSCA KI mice suggest normal PSCA expression in stomach, bone marrow, and kidney likely will not increase dose to these organs. Additionally, these mice have an intact immune system, which can be activated by radiation-induced DNA damage and can affect both therapeutic efficacy and toxicity [44].

Future studies include testing alpha-emitting radionuclides, which may be more effective in treating small lesions and metastases compared to beta-emitters [34]. This is because alpha emitters can deposit a lethal dose (high linear energy transfer $80-100 \mathrm{keV} / \mu \mathrm{m}$ ) to a few target cells (max path length $\sim 25-80 \mu \mathrm{m}$ ) while sparing surrounding tissues, which could pair well with a fragment that can penetrate into the lesion. Another group successfully used the A11 Mb labeled with astatine-211 for RIT of both subcutaneous and intratibial tumors [45]. Together with our results, both alpha- and beta-particle-labeled A11 Mb RIT are viable options, and further studies can also test sequential and cocktail alpha/beta administration [46]. Other optimization strategies include testing dose fractionation and combination therapy with chemotherapeutics.

As a humanized antibody fragment, $\mathrm{A} 11 \mathrm{Mb}$ is suitable for clinical translation. Clinical interest in alpha- and beta-particle targeted radiotherapy of prostate cancer has focused on PSMA-targeted radioligands such as ${ }^{177} \mathrm{Lu}$ or ${ }^{225}$ Ac-labeled PSMA-617 [8, 47]), which have shown efficacy, although salivary gland toxicity has been a concern [48]. In comparison, PSCA expression in normal tissues is more restricted (bladder, prostate, stomach), and uptake in off-target tissues was not observed in hPSCA KI mice in our study. Therefore, anti-PSCA antibody fragments could be a viable alternative providing fewer side effects. PSCA-targeted RIT may also be extended to pancreatic and bladder cancer patients, although additional dosimetry studies would need to be completed. 


\section{Conclusion}

Beta-emitter-labeled A11 Mb was evaluated for radioimmunotherapy of PSCA-positive prostate cancer. Iodine-131 and lutetium-177 dosimetry calculations showed $\left[{ }^{131} \mathrm{I}\right] \mathrm{I}-\mathrm{A} 11 \mathrm{Mb}$ could deliver a higher therapeutic dose while minimizing off-target effects. $\left[{ }^{131} \mathrm{I}\right] \mathrm{I}-\mathrm{A} 11 \mathrm{Mb}$ radioimmunotherapy successfully inhibited tumor growth and extended survival of mice with PSCA-positive s.c. xenografts. These results show anti-PSCA antibody fragments may be effective agents for prostate cancer radioimmunotherapy in the clinic. Furthermore, the minibody can be radiolabeled with a positron-emitting radionuclide for imaging, followed by a therapeutic radionuclide for treatment. Pre-therapy imaging could be used to evaluate target expression for patient selection and provide dosimetry to inform personalized treatment. Concomitant imaging and radioimmunotherapy can be employed to confirm dose delivery, and follow-up imaging can be used to evaluate therapeutic efficacy. In conclusion, radiolabeled antibody fragments such as $\mathrm{A} 11 \mathrm{Mb}$ have the potential to be powerful theranostic tools for integrated prostate cancer imaging and therapy.

\section{Supplementary Material}

Refer to Web version on PubMed Central for supplementary material.

\section{Acknowledgements}

The authors thank Dr. Paul Yazaki for purification of A11 Mb, Felix B. Salazar, Dr. Naoko Kobayashi, and Johnny Guan for technical support, Dr. Sophie Poty, Dr. Xiaoxi Ling, Dr. Roger Slavik, and Dr. Jason Lee for technical advice, Ngan Doan and the UCLA Translational Pathology Core Laboratory (TPCL) for histology sample preparation, Aulani Navarro-King and UCLA Division of Laboratory Animal Medicine for blood and serum sample analysis, Dr. Erik Larsson for providing the mouse S factors, and the UCLA Statistical Consulting Group for statistics assistance.

Funding

This work was supported by National Institute of Health grant R01 CA174294. The Small Animal Imaging Facility and TPCL services were supported by Jonsson Comprehensive Cancer Center (JCCC) (P30 CA016042). AM Wu is a member of JCCC.

\section{References}

1. Mottet N, Bellmunt J, Briers E, Bolla M, Bourke L, Cornford P, De Santis M, Henry AM, Joniau S, Lam TB, Mason MD, Van den Poel H, Van den Kwast TH, et al. (2018). EAU - ESTRO - ESUR SIOG Guidelines on Prostate Cancer.

2. Antonarakis ES, Lu C, Wang H, Luber B, Nakazawa M, Roeser JC, Chen Y, Mohammad TA, Chen Y, Fedor HL, Lotan TL, Zheng Q, De Marzo AM, et al. AR-V7 and resistance to enzalutamide and abiraterone in prostate cancer. N Engl J Med. 2014; 371: 1028-38. doi: 10.1056/NEJMoa1315815. [PubMed: 25184630]

3. Evans-Axelsson S, Timmermand OV, Bjartell A, Strand SE, Elgqvist J. Radioimmunotherapy for Prostate Cancer-Current Status and Future Possibilities. Semin Nucl Med. 2016; 46: 165-79. doi: 10.1053/j.semnuclmed.2015.10.005. [PubMed: 26897720]

4. Tagawa ST, Beltran H, Vallabhajosula S, Goldsmith SJ, Osborne J, Matulich D, Petrillo K, Parmar S, Nanus DM, Bander NH. Anti-prostate-specific membrane antigen-based radioimmunotherapy for prostate cancer. Cancer. 2010; 116: 1075-83. doi: 10.1002/cncr.24795. [PubMed: 20127956]

5. Tagawa ST, Milowsky MI, Morris M, Vallabhajosula S, Christos P, Akhtar NH, Osborne J, Goldsmith SJ, Larson S, Taskar NP, Scher HI, Bander NH, Nanus DM. Phase II study of Lutetium-177-labeled anti-prostate-specific membrane antigen monoclonal antibody J591 for 
metastatic castration-resistant prostate cancer. Clin Cancer Res. 2013; 19: 5182-91. doi: 10.1158/1078-0432.CCR-13-0231. [PubMed: 23714732]

6. Vilhelmsson Timmermand O, Larsson E, Ulmert D, Tran TA, Strand S. Radioimmunotherapy of prostate cancer targeting human kallikrein-related peptidase 2. EJNMMI Res 2016; 6: 27. doi: 10.1186/s13550-016-0181-z. [PubMed: 26983637]

7. Calopedos RJS, Chalasani V, Asher R, Emmett L, Woo HH. Lutetium-177-labelled anti-prostatespecific membrane antigen antibody and ligands for the treatment of metastatic castrate-resistant prostate cancer: a systematic review and meta-analysis. Prostate Cancer Prostatic Dis. 2017; 20:352-360. doi: 10.1038/pcan.2017.23. [PubMed: 28440324]

8. Rahbar K, Ahmadzadehfar H, Kratochwil C, Haberkorn U, Schafers M, Essler M, Baum RP, Kulkarni HR, Schmidt M, Drzezga A, Bartenstein P, Pfestroff A, Luster M, et al. German Multicenter Study Investigating 177Lu-PSMA-617 Radioligand Therapy in Advanced Prostate Cancer Patients. J Nucl Med. 2017; 58: 85-90. doi: 10.2967/jnumed.116.183194. [PubMed: 27765862]

9. Gu Z, Thomas G, Yamashiro J, Shintaku IP, Dorey F, Raitano A, Witte ON, Said JW, Loda M, Reiter RE. Prostate stem cell antigen (PSCA) expression increases with high gleason score, advanced stage and bone metastasis in prostate cancer. Oncogene. 2000; 19: 1288-96. doi: 10.1038/ sj.onc.1203426. [PubMed: 10713670]

10. Olafsen T, Gu Z, Sherman MA, Leyton JV, Witkosky ME, Shively JE, Raubitschek AA, Morrison SL, Wu AM, Reiter RE. Targeting, imaging, and therapy using a humanized antiprostate stem cell antigen (PSCA) antibody. J Immunother. 2007; 30: 396-405. doi: 10.1097/ CJI.0b013e318031b53b. [PubMed: 17457214]

11. Schwartz J, Humm JL, Divgi CR, Larson SM, O’Donoghue JA. Bone marrow dosimetry using 124I-PET. J Nucl Med. 2012; 53: 615-21. doi: 10.2967/jnumed.111.096453. [PubMed: 22414633]

12. Bander NH, Milowsky MI, Nanus DM, Kostakoglu L, Vallabhajosula S, Goldsmith SJ. Phase I trial of 177lutetium-labeled J591, a monoclonal antibody to prostate-specific membrane antigen, in patients with androgen-independent prostate cancer. J Clin Oncol. 2005; 23: 4591-601. doi: 10.1200/JCO.2005.05.160. [PubMed: 15837970]

13. Loke KS, Padhy AK, Ng DC, Goh AS, Divgi C. Dosimetric considerations in radioimmunotherapy and systemic radionuclide therapies: a review. World J Nucl Med. 2011; 10: 122-38. doi: 10.4103/1450-1147.89780. [PubMed: 22144871]

14. Goldenberg DM, Sharkey RM, Paganelli G, Barbet J, Chatal JF. Antibody pretargeting advances cancer radioimmunodetection and radioimmunotherapy. J Clin Oncol. 2006; 24: 823-34. doi: 10.1200/JCO.2005.03.8471. [PubMed: 16380412]

15. van Rij CM, Frielink C, Goldenberg DM, Sharkey RM, Lutje S, McBride WJ, Oyen WJ, Boerman OC. Pretargeted Radioimmunotherapy of Prostate Cancer with an Anti-TROP-2xAnti-HSG Bispecific Antibody and a (177)Lu-Labeled Peptide. Cancer Biother Radiopharm. 2014; 29: 3239. doi: 10.1089/cbr.2014.1660. [PubMed: 25226447]

16. Kenanova V, Olafsen T, Williams LE, Ruel NH, Longmate J, Yazaki PJ, Shively JE, Colcher D, Raubitschek AA, Wu AM. Radioiodinated versus radiometal-labeled anti-carcinoembryonic antigen single-chain Fv-Fc antibody fragments: optimal pharmacokinetics for therapy. Cancer Res. 2007; 67: 718-26. doi: 10.1158/0008-5472.CAN-06-0454. [PubMed: 17234783]

17. El-Emir E, Dearling JL, Huhalov A, Robson MP, Boxer G, Neri D, van Dongen GA, Trachsel E, Begent RH, Pedley RB. Characterisation and radioimmunotherapy of L19-SIP, an anti-angiogenic antibody against the extra domain B of fibronectin, in colorectal tumour models. Br J Cancer. 2007; 96: 1862-70. doi: 10.1038/sj.bjc.6603806. [PubMed: 17519905]

18. Viola-Villegas NT, Sevak KK, Carlin SD, Doran MG, Evans HW, Bartlett DW, Wu AM, Lewis JS. Noninvasive Imaging of PSMA in prostate tumors with (89)Zr-Labeled huJ591 engineered antibody fragments: the faster alternatives. Mol Pharm. 2014; 11: 3965-73. doi: 10.1021/ mp500164r. [PubMed: 24779727]

19. Knowles SM, Tavare R, Zettlitz KA, Rochefort MM, Salazar FB, Jiang ZK, Reiter RE, Wu AM. Applications of immunoPET: using 124I-anti-PSCA A11 minibody for imaging disease progression and response to therapy in mouse xenograft models of prostate cancer. Clin Cancer Res. 2014; 20: 6367-78. doi: 10.1158/1078-0432.CCR-14-1452. [PubMed: 25326233] 
20. Knowles SM, Zettlitz KA, Tavare R, Rochefort MM, Salazar FB, Stout DB, Yazaki PJ, Reiter RE, Wu AM. Quantitative immunoPET of prostate cancer xenografts with 89Zr- and 124I-labeled antiPSCA A11 minibody. J Nucl Med. 2014; 55: 452-9. doi: 10.2967/jnumed.113.120873. [PubMed: 24504052]

21. Tsai WK, Zettlitz KA, Tavare R, Kobayashi N, Reiter RE, Wu AM. Dual-modality immunoPET/ fluorescence imaging of prostate cancer with an anti-PSCA cys-minibody. Theranostics. 2018; 8: 5903-14. doi: 10.7150/thno.27679. [PubMed: 30613270]

22. Kassis AI. Therapeutic radionuclides: biophysical and radiobiologic principles. Semin Nucl Med. 2008; 38: 358-66. doi: 10.1053/j.semnuclmed.2008.05.002. [PubMed: 18662557]

23. Bavelaar BM, Lee BQ, Gill MR, Falzone N, Vallis KA. Subcellular Targeting of Theranostic Radionuclides. Front Pharmacol 2018; 9: 996. doi: 10.3389/fphar.2018.00996. [PubMed: 30233374]

24. Tsai WK, Wu AM. Aligning physics and physiology: Engineering antibodies for radionuclide delivery. J Labelled Comp Radiopharm. 2018; 16:693-714. doi: 10.1002/jlcr.3622.

25. Hens M, Vaidyanathan G, Welsh P, Zalutsky MR. Labeling internalizing anti-epidermal growth factor receptor variant III monoclonal antibody with (177)Lu: in vitro comparison of acyclic and macrocyclic ligands. Nucl Med Biol 2009; 36: 117-28. doi: 10.1016/j.nucmedbio.2008.11.001. [PubMed: 19217523]

26. Rogers BE, Franano FN, Duncan JR, Edwards WB, Anderson CJ, Connett JM, Welch MJ. Identification of metabolites of 111In-diethylenetriaminepentaacetic acid-monoclonal antibodies and antibody fragments in vivo. Cancer Res. 1995; 55: 5714s-20s. [PubMed: 7493333]

27. Saffran DC, Raitano AB, Hubert RS, Witte ON, Reiter RE, Jakobovits A. Anti-PSCA mAbs inhibit tumor growth and metastasis formation and prolong the survival of mice bearing human prostate cancer xenografts. Proc Natl Acad Sci U S A. 2001; 98: 2658-63. doi: 10.1073/pnas.051624698. [PubMed: 11226295]

28. Zhang M, Kobayashi N, Zettlitz KA, Kono EA, Yamashiro JM, Tsai WK, Jiang ZK, Tran CP, Wang C, Guan J, Wu AM, Reiter RE. Near-infrared-dye labeled anti-Prostate Stem Cell Antigen minibody enables real-time fluorescence imaging and targeted surgery in translational mouse models. Clinical Cancer Research 2018; 25:188-200.. doi: 10.1158/1078-0432.CCR-18-1382. [PubMed: 30301826]

29. Zettlitz KA, Tavare R, Knowles SM, Steward KK, Timmerman JM, Wu AM. ImmunoPET of Malignant and Normal B Cells with (89)Zr- and (124)I-Labeled Obinutuzumab Antibody Fragments Reveals Differential CD20 Internalization In Vivo. Clin Cancer Res. 2017; 23: 7242 52. doi: 10.1158/1078-0432.CCR-17-0855. [PubMed: 28928164]

30. Sosabowski JK, Mather SJ. Conjugation of DOTA-like chelating agents to peptides and radiolabeling with trivalent metallic isotopes. Nat Protoc. 2006; 1: 972-6. doi: 10.1038/ nprot.2006.175. [PubMed: 17406332]

31. Lepin EJ, Leyton JV, Zhou Y, Olafsen T, Salazar FB, McCabe KE, Hahm S, Marks JD, Reiter RE, Wu AM. An affinity matured minibody for PET imaging of prostate stem cell antigen (PSCA)expressing tumors. Eur J Nucl Med Mol Imaging. 2010; 37: 1529-38. doi: 10.1007/ s00259-010-1433-1. [PubMed: 20354850]

32. Loening AM, Gambhir SS. AMIDE: a free software tool for multimodality medical image analysis. Mol Imaging. 2003; 2: 131-7. [PubMed: 14649056]

33. Larsson E, Ljungberg M, Strand SE, Jonsson BA. Monte Carlo calculations of absorbed doses in tumours using a modified MOBY mouse phantom for pre-clinical dosimetry studies. Acta Oncol 2011; 50: 973-80. doi: 10.3109/0284186X.2011.582517. [PubMed: 21767199]

34. Larson SM, Carrasquillo JA, Cheung NK, Press OW. Radioimmunotherapy of human tumours. Nat Rev Cancer. 2015; 15: 347-60. doi: 10.1038/nrc3925. [PubMed: 25998714]

35. Stabin MG, Sparks RB, Crowe E. OLINDA/EXM: the second-generation personal computer software for internal dose assessment in nuclear medicine. J Nucl Med. 2005; 46: 1023-7. doi: [PubMed: 15937315]

36. Stabin MG. Health concerns related to radiation exposure of the female nuclear medicine patient. Environ Health Perspect. 1997; 105 Suppl 6: 1403-9. doi: 10.1289/ehp.97105s61403. [PubMed: 9467052] 
37. Tijink BM, Neri D, Leemans CR, Budde M, Dinkelborg LM, Stigter-van Walsum M, Zardi L, van Dongen GA. Radioimmunotherapy of head and neck cancer xenografts using 131I-labeled antibody L19-SIP for selective targeting of tumor vasculature. J Nucl Med. 2006; 47: 1127-35. doi: [PubMed: 16818947]

38. Tavare R, McCracken MN, Zettlitz KA, Knowles SM, Salazar FB, Olafsen T, Witte ON, Wu AM. Engineered antibody fragments for immuno-PET imaging of endogenous CD8+ T cells in vivo. Proc Natl Acad Sci U S A. 2014; 111: 1108-13. doi: 10.1073/pnas.1316922111. [PubMed: 24390540]

39. Violet JA, Jackson P, Ferdinandus J, Sandhu S, Akhurst T, Iravani A, Kong G, Ravi Kumar A, Thang SP, Eu P, Scalzo M, Murphy D, Williams SG, et al. Dosimetry of 177Lu-PSMA-617 in metastatic castration-resistant prostate cancer: correlations between pretherapeutic imaging and whole body tumor dosimetry with treatment outcomes. J Nucl Med. 2019; 60:517-523. doi: 10.2967/jnumed.118.219352. [PubMed: 30291192]

40. Conti PS, White C, Pieslor P, Molina A, Aussie J, Foster P. The role of imaging with (111)Inibritumomab tiuxetan in the ibritumomab tiuxetan (zevalin) regimen: results from a Zevalin Imaging Registry. J Nucl Med. 2005; 46: 1812-8. doi: [PubMed: 16269594]

41. Sakata M, Oda K, Toyohara J, Ishii K, Nariai T, Ishiwata K. Direct comparison of radiation dosimetry of six PET tracers using human whole-body imaging and murine biodistribution studies. Ann Nucl Med. 2013; 27: 285-96. doi: 10.1007/s12149-013-0685-9. [PubMed: 23404061]

42. Zhang M, Kobayashi N, Zettlitz KA, Kono EA, Yamashiro JM, Tsai WK, Jiang ZK, Tran CP, Wang C, Guan J, Wu AM, Reiter RE. Near-Infrared Dye-Labeled Anti-Prostate Stem Cell Antigen Minibody Enables Real-Time Fluorescence Imaging and Targeted Surgery in Translational Mouse Models. Clin Cancer Res. 2019; 25: 188-200. doi: 10.1158/1078-0432.CCR-18-1382. [PubMed: 30301826]

43. Zettlitz KA, Tsai WK, Knowles SM, Salazar FB, Kobayashi N, Reiter RE, Wu AM. [(89)Zr]A2cDb Immuno-PET of Prostate Cancer in a Human Prostate Stem Cell Antigen Knock-in (hPSCA KI) Syngeneic Model. Mol Imaging Biol 2019; 22:367-376. doi: 10.1007/ s11307-019-01386-7.

44. Hwang WL, Pike LRG, Royce TJ, Mahal BA, Loeffler JS. Safety of combining radiotherapy with immune-checkpoint inhibition. Nat Rev Clin Oncol. 2018; 15: 477-94. doi: 10.1038/ s41571-018-0046-7. [PubMed: 29872177]

45. Bäck T, Jennbacken K, Olafsen T, Hagberg-Thulin M, Lindegren S, Jensen H, Yazaki PJ, Palm S, Albertsson P, Damber JE, Wu AM, Welen K. Targeted alpha therapy with astatine-211 labeled anti-PSCA A11 minibody shows strong antitumor efficacy in prostate cancer xenografts and bone microtumors. Eur. J. Nucl.Med.Molec.Imag. Res. 2020; 10:10. doi: 10.1186/s13550-020-0600-z.

46. Haberkorn UA, Giesel F, Morgenstern A, Kratochwil C. The Future of Radioligand Therapy: Alpha, beta or both? J Nucl Med. 2017; 58:1017-1018. doi: 10.2967/jnumed.117.190124. [PubMed: 28408527]

47. Kratochwil C, Bruchertseifer F, Giesel FL, Weis M, Verburg FA, Mottaghy F, Kopka K, Apostolidis C, Haberkorn U, Morgenstern A. 225Ac-PSMA-617 for PSMA-Targeted alphaRadiation Therapy of Metastatic Castration-Resistant Prostate Cancer. J Nucl Med. 2016; 57: 1941-4. doi: 10.2967/jnumed.116.178673. [PubMed: 27390158]

48. Kratochwil C, Bruchertseifer F, Rathke H, Bronzel M, Apostolidis C, Weichert W, Haberkorn U, Giesel FL, Morgenstern A. Targeted alpha-Therapy of Metastatic Castration-Resistant Prostate Cancer with 225Ac-PSMA-617: Dosimetry Estimate and Empiric Dose Finding. J Nucl Med. 2017; 58: 1624-31. doi: 10.2967/jnumed.117.191395. [PubMed: 28408529] 
a

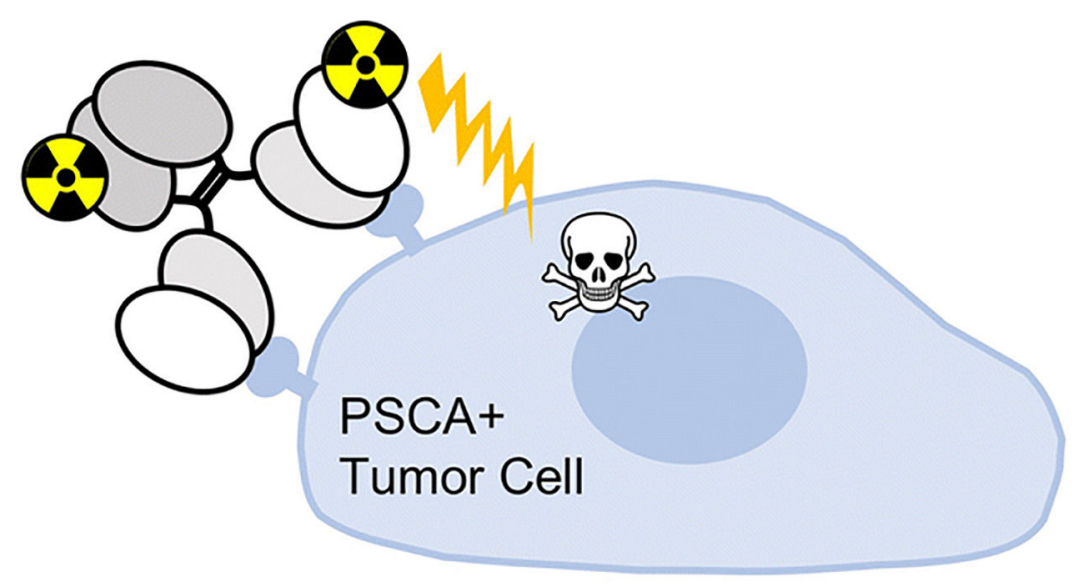

$\mathrm{b}$

$\mathrm{A} 11 \mathrm{Mb}$
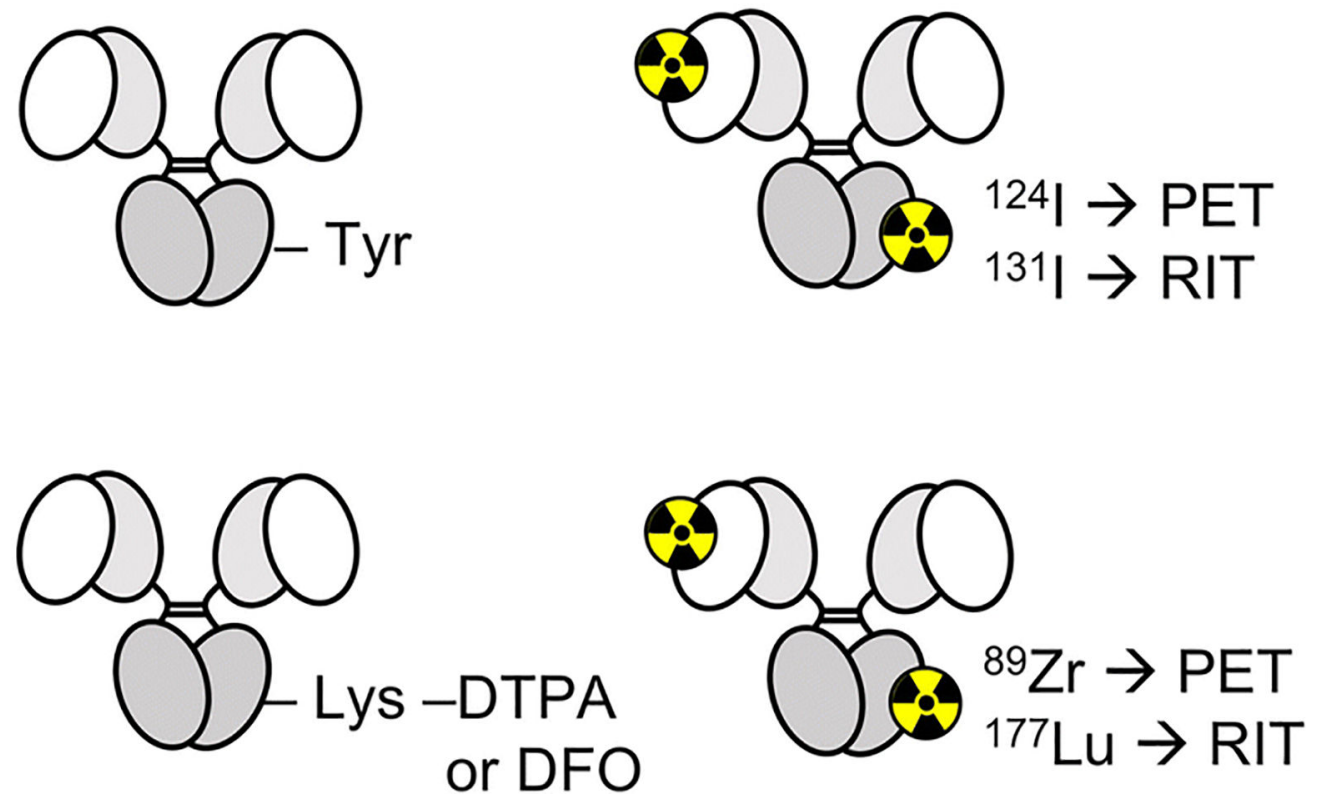

FIGURE 1: Schematic of RIT using radiolabeled A11 Mb.

A, A11 Mb targets PSCA-positive prostate cancer cells, and the beta-emission from the radionuclide reaches throughout the tumor and causes DNA and ROS damage. $\mathbf{B}, \mathrm{A} 11 \mathrm{Mb}$ is radiolabeled with iodine-124 for PET imaging and iodine-131 for RIT. A11 Mb is conjugated to SCN-DFO or p-SCN-Bn-CHX-A"-DTPA for zirconium-89 and lutetium-177 radiolabeling, respectively. $\mathrm{DFO}=$ deferoxamine, $\mathrm{DTPA}=$ diethylenetriaminepentaacetic acid, Lys=lysine, $\mathrm{Mb}=$ minibody, $\mathrm{PET}=$ positron emission tomography, PSCA=prostate stem cell antigen, RIT=radioimmunotherapy, Tyr=tyrosine. 


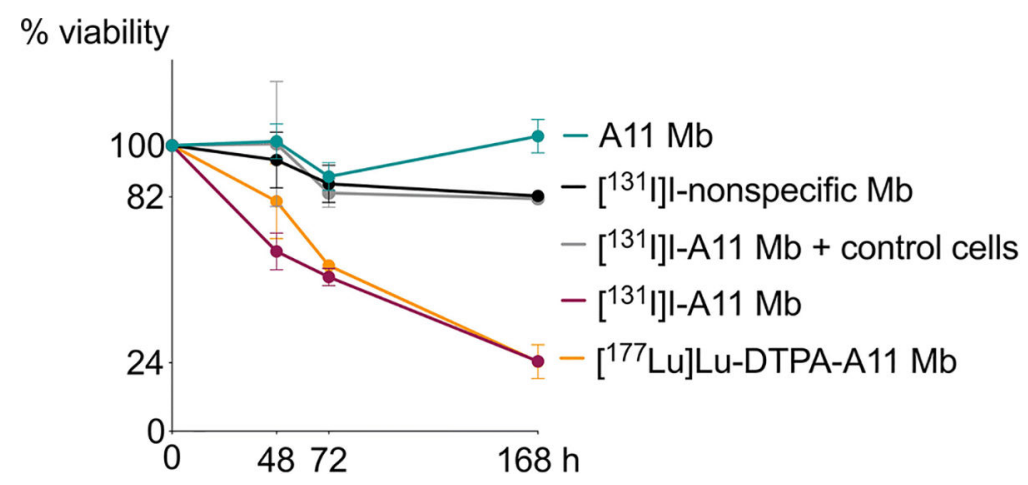

FIGURE 2: [ ${ }^{131}$ I]I-A11 Mb and [ $\left.{ }^{177} \mathrm{Lu}\right]$ Lu-DTPA-A11 Mb inhibit PSCA-positive cell growth in vitro.

In a cell cytotoxicity assay, $0.19 \mathrm{MBq}\left[{ }^{131} \mathrm{I}\right] \mathrm{I}-\mathrm{A} 11 \mathrm{Mb}$ and $\left[{ }^{177} \mathrm{Lu}\right] \mathrm{Lu}-\mathrm{DTPA}-\mathrm{A} 11 \mathrm{Mb}$ treatments result in $24 \%$ viability of $22 \mathrm{Rv} 1$-PSCA prostate adenocarcinoma cells, compared to little to no inhibition of tumor cell growth in ${ }^{131}$ I-labeled nonspecific $\mathrm{Mb}$ and unlabeled A11 Mb control groups, as well as [ $\left.{ }^{131} \mathrm{I}\right] \mathrm{I}-\mathrm{A} 11 \mathrm{Mb}$ added to PSCA-negative 22Rv1 cells. 
a<smiles>[14CH3][14CH3]</smiles>

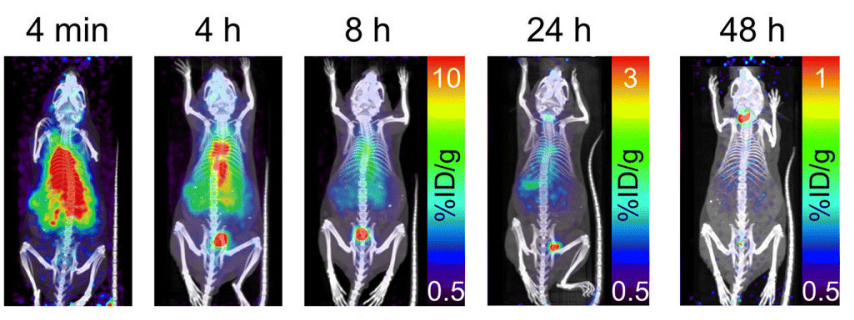

C $\left[{ }^{89} \mathrm{Zr}\right] \mathrm{Zr}-\mathrm{DFO}-\mathrm{A} 11 \mathrm{Mb}$

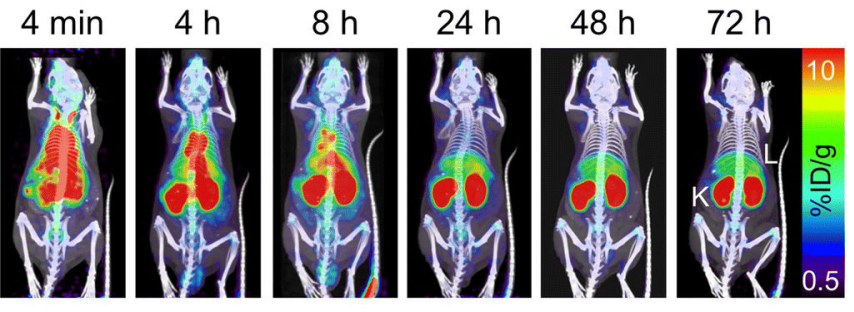

b

$\left[{ }^{124} \mathrm{I}\right] \mathrm{I}-\mathrm{A} 11 \mathrm{Mb}$

$\% \mathrm{ID} / \mathrm{g}$

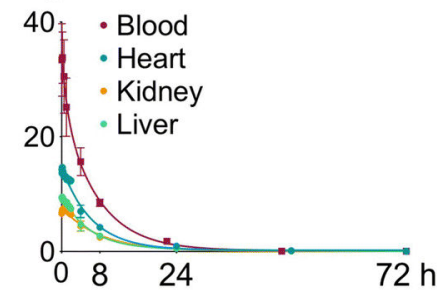

d $\quad\left[{ }^{89} \mathrm{Zr}\right] \mathrm{Zr}-\mathrm{DFO}-\mathrm{A} 11 \mathrm{Mb}$

$\% \mathrm{ID} / \mathrm{g}$

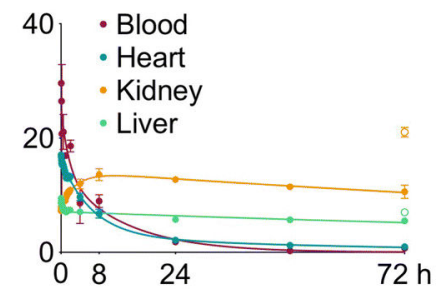

FIGURE 3: Serial immunoPET/CT of non-tumor-bearing nude mice.

A, $\left[{ }^{124} \mathrm{I}\right] \mathrm{I}-\mathrm{A} 11 \mathrm{Mb}(\mathrm{n}=3)$ PET/CT images show whole body and bladder activity clears by 24-48 h (little to no activity seen at $72 \mathrm{~h}$ ). B, $\left[{ }^{124} \mathrm{I}\right] \mathrm{I}-\mathrm{A} 11 \mathrm{Mb}$ ROI analysis confirms activity clears from the blood and organs by 24 hours. For the $72 \mathrm{~h}$ data points, $\% \mathrm{ID} / \mathrm{g}$ calculated from ex vivo biodistribution for heart, liver, and kidney, was plotted due to activity clearance and inability to quantify using ROI analysis. C, $\left.{ }^{89} \mathrm{Zr}\right] \mathrm{Zr}$-DFO-A11 Mb PET/CT images $(n=3)$ show activity clears from blood pool by $24 \mathrm{~h}$, and clearance to kidney and liver results in high activity even at $72 \mathrm{~h}$. L=liver, K=kidney. $\mathbf{D}$, [ $\left.{ }^{89} \mathrm{Zr}\right] \mathrm{Zr}-\mathrm{DFO}-\mathrm{A} 11 \mathrm{Mb}$ ROI analysis show high activity in the organs of clearance, liver and kidneys, at 72 hours. At $72 \mathrm{~h}$, the kidney \%ID/g from ex vivo biodistribution (open circle) is higher than calculated from ROI, likely due to partial volume effect. ROI analysis was completed by averaging \%ID/g from 3 spheres placed in the heart and each kidney, and 6 spheres in the liver. 

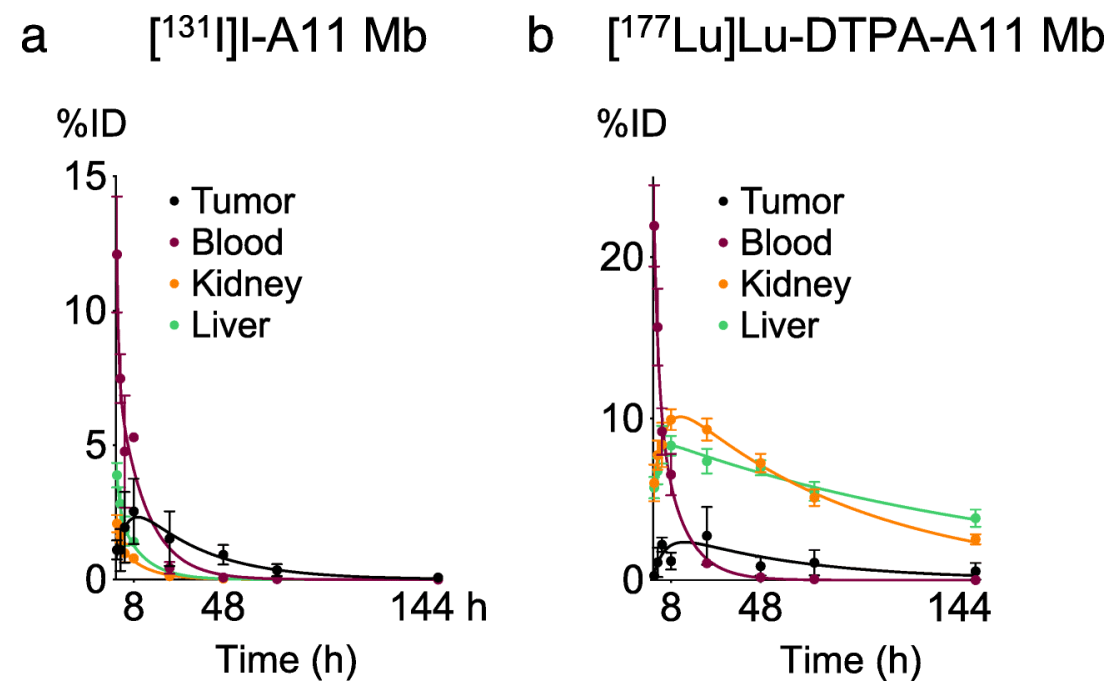

FIGURE 4: Biodistribution time activity curves used for RIT dose estimation.

A, $\left[{ }^{131} \mathrm{I}\right] \mathrm{I}-\mathrm{A} 11 \mathrm{Mb}$ and $\mathbf{B},\left[{ }^{177} \mathrm{Lu}\right] \mathrm{Lu}-\mathrm{DTPA}-\mathrm{A} 11 \mathrm{Mb}$ biodistributions in 22Rv1-PSCA s.c. tumor-bearing mice ( $\mathrm{n}=4$ per time point) show peak tumor uptake at 8 hours. As expected, high activity is retained in the liver and kidneys at 72 hours in mice injected with $\left[{ }^{177} \mathrm{Lu}\right] \mathrm{Lu}-$ DTPA-A11 Mb. The area under the curve for \%ID per organ was used for dosimetry estimation. 


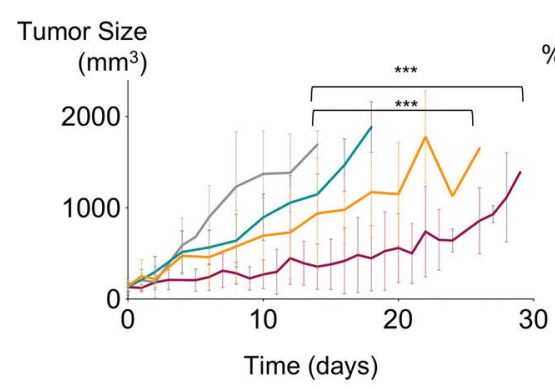

C

Tumor weight

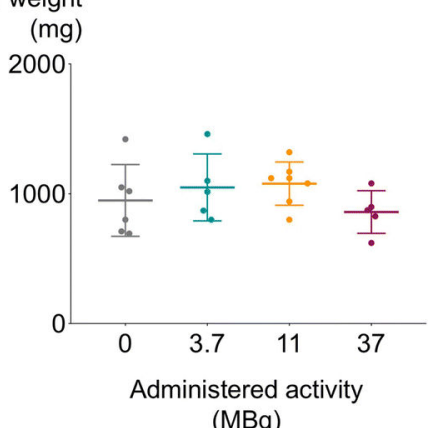

b

$\%$ Survival

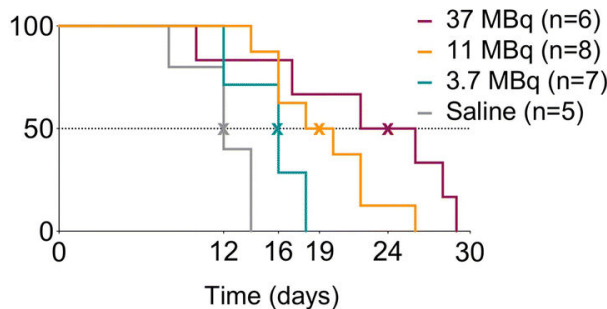

d

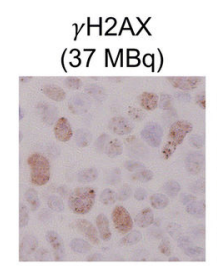

PSCA

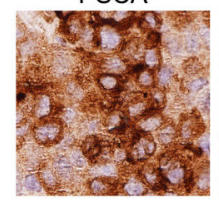

$\gamma \mathrm{H} 2 \mathrm{AX}$

(saline)

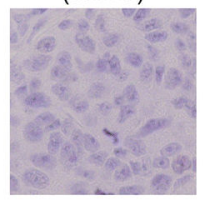

HE

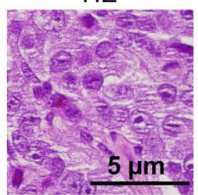

FIGURE 5: $\left[{ }^{131}\right.$ I]I-A11 Mb RIT inhibits tumor growth and extends survival in a dose-dependent manner.

A, A single dose of $\left[{ }^{131} \mathrm{I}\right] \mathrm{I}-\mathrm{A} 11 \mathrm{Mb}$ delays tumor growth in $37 \mathrm{MBq}(\mathrm{n}=6), 11 \mathrm{MBq}(\mathrm{n}=8)$, and $3.7 \mathrm{MBq}(\mathrm{n}=7)$ therapy groups compared to saline control $(\mathrm{n}=5)$. ***P<0.001. B, Kaplan-Meier survival curves of mice administered $37 \mathrm{MBq}$ (median=24 d) and $11 \mathrm{MBq}$ $\left[{ }^{131} \mathrm{I}\right] \mathrm{I}-\mathrm{A} 11 \mathrm{Mb}(19 \mathrm{~d})$ are significantly different $(\mathrm{P}=0.0009$ for both) compared to saline (12 d), while a nonsignificant effect is observed in the $3.7 \mathrm{MBq}$ group. $\mathbf{C}$, The average tumor weight at the time of sacrifice was similar among all groups: $830 \mathrm{mg}$ (37 MBq), $1050 \mathrm{mg}$ (11 MBq), $1060 \mathrm{mg}$ (3.7 MBq), and $940 \mathrm{mg}$ (saline). D, Compared to control, at $48 \mathrm{~h}$ tumors in the $37 \mathrm{MBq}$ group express gamma $\mathrm{H} 2 \mathrm{AX}$, a marker for DNA damage. PSCA expression was also confirmed. 


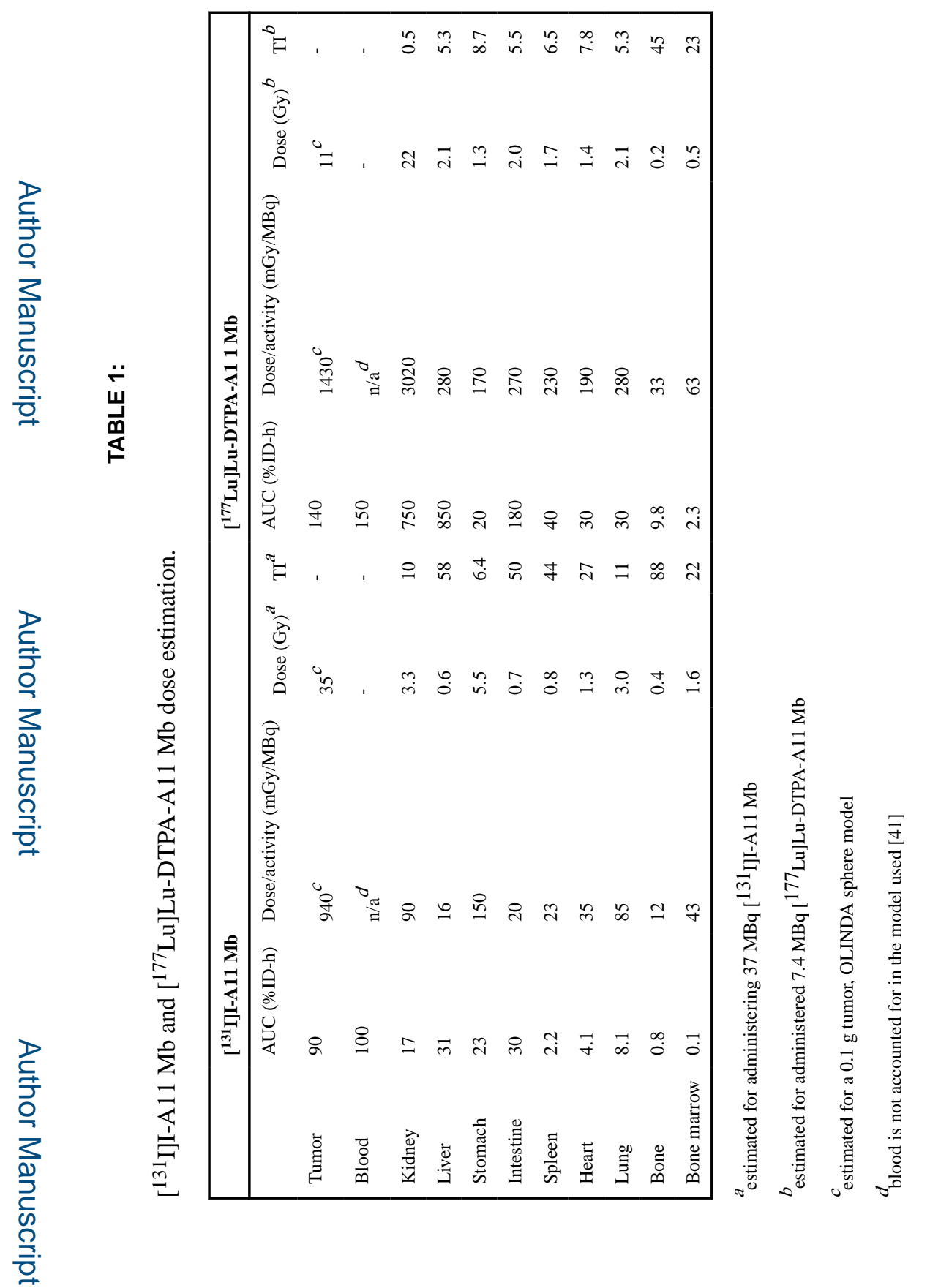

Mol Imaging Biol. Author manuscript; available in PMC 2021 October 01. 